\title{
Synthesis, Structure Evaluation, Spectroscopic and Antibacterial Investigation of Metal Complexes with 2-(Pyridin-4-yl)quinoline-4-carboxylic Acid
}

\author{
Long Zhang, ${ }^{\dagger}$ Zhong-Wei Man, ${ }^{\dagger}$ Yan Zhang, Jing Hong, Meng-Ran Guo \\ and Jie Qin*
}

\author{
School of Life Sciences, Shandong University of Technology, Zibo 255049, P. R. China \\ * Corresponding author: E-mail: qinjietutu@ 163.com \\ Tel.: 0086-533-2780271; Fax: 0086-533-2781329.
}

Received: 07-09-2016

${ }^{\dagger}$ These authors contributed equally to this work.

\begin{abstract}
Four metal complexes based on quinoline carboxylate ligand from 2-(pyridin-4-yl)quinoline-4-carboxylic acid (HL), $\left\{\left[\mathrm{ML}_{2}\left(\mathrm{H}_{2} \mathrm{O}\right)_{2}\right] \cdot 2 \mathrm{H}_{2} \mathrm{O}\right\}_{\mathrm{n}}\left(\mathrm{M}=\mathrm{Mn}^{\mathrm{II}}, \mathbf{1} ; \mathrm{M}=\mathrm{Co}^{\mathrm{II}}, \mathbf{2} ; \mathrm{M}=\mathrm{Cd}^{\mathrm{II}}, \mathbf{3}\right)$ and $\left\{\left[\mathrm{Ag}_{2} \mathrm{~L}_{2}\left(\mathrm{H}_{2} \mathrm{O}\right)_{2}\right] \cdot 3 \mathrm{H}_{2} \mathrm{O}\right\}_{\mathrm{n}}(\mathbf{4})$ have been synthesized under hydrothermal conditions. Their structures were determined by elemental analyses, IR spectra, and further characterized by single-crystal X-ray diffraction analysis. Complexes 1-3 feature a 1D chain structure which is further linked together to construct the 3D supramolecular network through hydrogen bonds. Complex 4 exhibits a 3D configuration. The fluorescent behavior and antibacterial activities of these compounds have been investigated.
\end{abstract}

Keywords: Quinoline derivative; X-ray crystal structure; fluorescent property; antibacterial activity

\section{Introduction}

Since Pt-based drugs play a significant role in antitumor chemotherapy, development of metal complexes possessing biological activities has been an active research field. ${ }^{1,2}$ The biological properties of metal complexes depend on the organic ligands and the nature of metal ions. Thereby, the combination of suitable metal ion as well as ligand is an important prerequisite for the construction of bioactive metal complex. ${ }^{3,4}$

Quinoline scaffold has been known for wide spectrum of biological and pharmaceutical activities, such as antimalarial, ${ }^{5,6}$ antitumor, ${ }^{7,8}$ antibacterial,,${ }^{9,10}$ and antiallergic. ${ }^{11}$ Carboxyl modified heterocycle compounds are also excellent metal-binding compounds, which exhibit versatile coordination modes depending on reaction conditions and the nature of central metal ion. ${ }^{12-14}$

In our earlier investigations, we have shown that dinuclear complexes of $\mathrm{Mn}(\mathrm{II}), \mathrm{Co}(\mathrm{II}), \mathrm{Cd}(\mathrm{II})$, and $\mathrm{Zn}(\mathrm{II})$ based on 2-phenylquinoline carboxylic derivatives $\mathbf{H L}_{\mathbf{1}}$ and $\mathbf{H L}_{\mathbf{2}}$ (Scheme 1) possess broad and effective antibacterial activity. ${ }^{14,15}$ These results prompted us to examine the controlling factors on the antibacterial activity of metal complex based on quinoline derivatives. In continuation of our work, this paper deals with the synthesis and characterization of four metal complexes, $\left\{\left[\mathrm{ML}_{2}\left(\mathrm{H}_{2} \mathrm{O}\right)_{2}\right]\right.$. $\left.2 \mathrm{H}_{2} \mathrm{O}\right\}\left(\mathrm{M}=\mathrm{Mn}^{\mathrm{II}}, \mathbf{1} ; \mathrm{M}=\mathrm{Co}^{\mathrm{II}}, \mathbf{2} ; \mathrm{M}=\mathrm{Cd}^{\mathrm{II}}, \mathbf{3}\right)$ and $\left\{\left[\mathrm{Ag}_{2} \mathrm{~L}_{2}\left(\mathrm{H}_{2} \mathrm{O}\right)_{2}\right] \cdot 4 \mathrm{H}_{2} \mathrm{O}\right\}_{\mathrm{n}}(4)$, derived from 2-pyridylinoline derivative 2-(pyridin-4-yl)quinoline-4-carboxylic acid (HL). The photoluminescent property and antibacterial assays over gram-positive and gram-negative bacterial strains are also presented in this manuscript.<smiles>[R]c1ccc(-c2cc(C(=O)O)c3ccccc3n2)cc1</smiles>

$\begin{array}{ll}\mathrm{R}=\mathrm{Br} & \mathrm{HL}_{1} \\ \mathrm{R}=\mathrm{F} & \mathrm{HL}_{2}\end{array}$<smiles>O=C(O)c1cc(-c2ccncc2)nc2ccccc12</smiles>

HL
Scheme 1. Structure of ligands $\mathrm{HL}_{1}, \mathbf{H L}_{2}$ and $\mathbf{H L}$. 


\section{Experimental Section}

\section{1. Materials and Instruments}

All the reactions were carried out under air atmosphere. All chemicals and solvents used in the synthesis were reagent grade without further purification.

The IR spectra were taken on a Vector22 Bruker spectrophotometer $\left(400-4000 \mathrm{~cm}^{-1)}\right.$ with $\mathrm{KBr}$ pellets. NMR spectra were measured on a Bruker AM 500 spectrometer. Elemental analyses for $\mathrm{C}, \mathrm{H}$ and $\mathrm{N}$ were performed on a Perkin-Elmer 240C analyzer. Fluorescence spectra were recorded on a Hitachi F-4500 fluorescence spectrophotometer.

\section{2. Synthesis of 2-(Pyridin-4-yl)quinoline-4- carboxylic Acid (HL)}

A mixture of isatin $(1.18 \mathrm{~g}, 8.00 \mathrm{mmol}), 4$-acetylpyridine $(0.24 \mathrm{~g}, 2.00 \mathrm{mmol})$, and potassium hydroxide $(2.24 \mathrm{~g}, 40.00 \mathrm{mmol})$ in $2 \mathrm{~mL}$ of ethanol and $18 \mathrm{~mL}$ of water was mixed and refluxed for 10 hours. When the reaction was finished, the orange solution was cooled to room temperature and adjusted to $\mathrm{pH} 5$ with $1 \mathrm{M} \mathrm{HCl}$. The synthetic yellow precipitate was filtered, washed several times with water and dried. Yield: $1.16 \mathrm{~g}, 58 \%$. IR $\left(\mathrm{KBr}, \mathrm{cm}^{-1}\right): 3431,3064,2759,2445,1942,1720,1609$, $1588,1541,1500,1456,1416,1348,1308,1253,1152$, $1060,1016,864,835,796,778,763,735,716,652 .{ }^{1} \mathrm{H}-$ NMR (500Hz, DMSO, $\delta): 8.79(\mathrm{~d}, J=5 \mathrm{~Hz}, 2 \mathrm{H}), 8.67(\mathrm{~d}$, $J=10 \mathrm{~Hz}, 1 \mathrm{H}), 8.46(\mathrm{~s}, 1 \mathrm{H}), 8.25(\mathrm{~d}, J=10 \mathrm{~Hz}, 2 \mathrm{H}), 8.19$ $(\mathrm{d}, J=10 \mathrm{~Hz}, 1 \mathrm{H}), 7.87(\mathrm{t}, 1 \mathrm{H}), 7.73(\mathrm{t}, 1 \mathrm{H})$. Anal. Calcd for $\mathrm{C}_{15} \mathrm{H}_{10} \mathrm{~N}_{2} \mathrm{O}_{2}$ : C, 71.99; $\mathrm{H}, 4.03 ; \mathrm{N}, 11.19$. Found: $\mathrm{C}$, $72.21 ; \mathrm{H}, 4.02 ; \mathrm{N}, 11.22 \%$.

\section{3. General Procedure for the Synthesis of Complexes 1-4}

HL $(0.10 \mathrm{mmol})$ and nitrates $\left(\mathrm{Mn}\left(\mathrm{NO}_{3}\right)_{2}, \mathrm{Co}\left(\mathrm{NO}_{3}\right)_{2}\right.$, $\mathrm{Cd}\left(\mathrm{NO}_{3}\right)_{2}$, or $\left.\mathrm{AgNO}_{3}\right)(0.10 \mathrm{mmol})$ in $10 \mathrm{~mL}$ mixed solvent of $\mathrm{DMF} / \mathrm{CH}_{3} \mathrm{OH} / \mathrm{H}_{2} \mathrm{O}(\mathrm{v} / \mathrm{v} / \mathrm{v}=2 / 4 / 4)$ were sealed in $25 \mathrm{~mL}$ Teflon cup and heated at $90{ }^{\circ} \mathrm{C}$ for $2-3$ days and cooled slowly to room temperature over a period of $20 \mathrm{~h}$. Then crystals suitable for $\mathrm{X}$-ray diffraction analysis were obtained.

$\left\{\left[\mathrm{MnL}_{2}\left(\mathrm{H}_{2} \mathrm{O}\right)_{2}\right] \cdot 2 \mathrm{H}_{2} \mathrm{O}\right\}_{\mathrm{n}}(1)$ Yield: $0.026 \mathrm{~g}(42 \%$ on the basis of $\mathbf{H L})$. IR $\left(\mathrm{KBr}, \mathrm{cm}^{-1}\right): 3214,1608,1581,1501$, 1421, 1396, 1327, 1308, 1239, 1067, 1013, 837, 813, 771, 655, 572, 546. Anal. Calcd. for $\mathrm{C}_{30} \mathrm{H}_{26} \mathrm{~N}_{4} \mathrm{O}_{8} \mathrm{Mn}$ : C, 57.61; H, 4.19; N: 8.96. Found: C, 57.78; H, 4.18; N, 8.99\%.

$\left\{\left[\mathrm{CoL}_{2}\left(\mathrm{H}_{2} \mathrm{O}\right)_{2}\right] \cdot 2 \mathrm{H}_{2} \mathrm{O}\right\}_{\mathrm{n}}(2)$ Yield: $0.035 \mathrm{~g}(56 \%$ on the basis of $\mathbf{H L})$. IR $\left(\mathrm{KBr}, \mathrm{cm}^{-1}\right)$ : 3217, 1953, 1611, 1582, 1502, 1458, 1422, 1398, 1329, 1309, 1239, 1068, 1018, 870, 838, 814, 772, 721, 684, 572, 555. Anal. Calcd. for $\mathrm{C}_{30} \mathrm{H}_{26} \mathrm{~N}_{4} \mathrm{O}_{8} \mathrm{Co}$ : C, 57.24; H, 4.16; N, 8.90. Found: C, $57.41 ; \mathrm{H}, 4.15 ; \mathrm{N}, 8.93 \%$.

$\left\{\left[\mathrm{CdL}_{2}\left(\mathrm{H}_{2} \mathrm{O}\right)_{2}\right] \cdot 2 \mathrm{H}_{2} \mathrm{O}\right\}_{\mathrm{n}}(3)$ Yield: $0.031 \mathrm{~g}(46 \%$ on the basis of $\mathbf{H L})$. IR $\left(\mathrm{KBr}, \mathrm{cm}^{-1}\right)$ : 3434, 3105, 1951, 1611,
$1552,1537,1498,1453,1425,1390,1324,1305,1239$, $1064,1020,866,838,804,785,660,573$. Anal. Calcd. for $\mathrm{C}_{30} \mathrm{H}_{26} \mathrm{~N}_{4} \mathrm{O}_{8} \mathrm{Cd}$ : C, 52.76; H, 3.84; N, 8.20. Found: C, $52.92 ; \mathrm{H}, 3.83 ; \mathrm{N}, 8.22 \%$.

$\left\{\left[\mathrm{Ag}_{2} \mathrm{~L}_{2}\left(\mathrm{H}_{2} \mathrm{O}\right)_{2}\right] \cdot 4 \mathrm{H}_{2} \mathrm{O}\right\}_{\mathrm{n}}$ (4) Yield: $0.035 \mathrm{~g}(43 \%$ on the basis of $\mathbf{H L})$. IR $\left(\mathrm{KBr}, \mathrm{cm}^{-1}\right): 3401,3080,3036,1948$, $1599,1574,1492,1455,1417,1380,1321,1152,1066$, 999, 864, 853, 814, 776, 720, 684, 571. Anal. Calcd. for $\mathrm{C}_{30} \mathrm{H}_{29} \mathrm{~N}_{4} \mathrm{O}_{10} \mathrm{Ag}_{2}: \mathrm{C}, 43.87 ; \mathrm{H}, 3.56 ; \mathrm{N}, 6.82$. Found: $\mathrm{C}$, $44.00 ; \mathrm{H}, 3.55 ; \mathrm{N}, 6.84 \%$.

\section{4. X-Ray Data Collection and Structure Refinement}

Structure measurements of all the complexes were performed on Bruker Smart Apex CCD diffractometer equipped with graphite-monochromated Mo K $\alpha$ with radiation wavelength of $0.71073 \AA$ by using a $\omega-2 \theta$ scan mode. The collected data were reduced using the SAINT program. ${ }^{16}$ Absorption corrections were applied using SADABS program. ${ }^{17}$ These structures were solved by direct methods and refined with the full-matrix least-squares technique using SHELXS-97. ${ }^{18}$ Anisotropic thermal parameters were assigned to all non-hydrogen atoms. The solvent molecules $\mathrm{O} 8$ and $\mathrm{O} 9$ in complex $\mathbf{4}$ were disordered over two positions (50: 50 occupancy). The hydrogen atoms bonded to $\mathrm{C}$ were generated geometrically; while the hydrogen atoms of the water molecules were located from difference maps and fixed at their ideal positions with $\mathrm{O}-\mathrm{H}=0.85(2)$ $\AA, \mathrm{H} \cdots \mathrm{H}=1.44(2) \AA$ and $U_{\text {iso }}(\mathrm{H})=1.5 U_{\text {eq }}(\mathrm{O})$.

\section{5. Bioassay Conditions}

Four referenced bacterial strains, B. subtilis, E. coli, $P$. aeruginosa and $S$. aureus-were selected. Streptomycin was used as a positive control. The $\mathrm{IC}_{50}$ (half minimum inhibitory concentrations) of the test compounds were determined by a colorimetric method using the dye MTT (3-(4,5-dimethylth-iazol-2-yl)-2,5-diphenyl tetrazoliumbromide). Stock solutions of the synthesized compounds $(100 \mu \mathrm{g} / \mathrm{mL})$ were prepared in DMSO, and sequentially diluted with Mueller-Hinton medium. The antibacterial activities were evaluated by the method reported before. ${ }^{14,15,19}$ The procedure of antimicrobial activity was given in detail in Supporting Information.

\section{Results and Discussion}

\section{1. Synthesis and General Characterization}

Complexes 1-4 were constructed from HL and the related metal salt under hydrothermal conditions. All of complexes are soluble in high polarity solvents.

HL was prepared via the Pfitzinger reaction. ${ }^{14}$ Characterization of the ligand has been accomplished by IR, $1 \mathrm{H}$ NMR, and elemental analysis. The FT-IR spectrum for 
Table 1. Crystallographic data for 1-4.

\begin{tabular}{|c|c|c|c|c|}
\hline Empirical formula & $\begin{array}{c}1 \\
\mathrm{C}_{30} \mathrm{H}_{26} \mathrm{~N}_{4} \mathrm{O}_{8} \mathrm{Mn} \\
\end{array}$ & $\begin{array}{c}2 \\
\mathrm{C}_{30} \mathrm{H}_{26} \mathrm{~N}_{4} \mathrm{O}_{8} \mathrm{Co} \\
\end{array}$ & $\begin{array}{c}3 \\
\mathrm{C}_{30} \mathrm{H}_{26} \mathrm{~N}_{4} \mathrm{O}_{8} \mathrm{Cd} \\
\end{array}$ & $\begin{array}{c}4 \\
\mathrm{C}_{30} \mathrm{H}_{28} \mathrm{~N}_{4} \mathrm{O}_{9} \mathrm{Ag}_{2} \\
\end{array}$ \\
\hline$M_{\mathrm{r}}$ & 625.49 & 629.48 & 682.95 & 804.30 \\
\hline Crystal system & triclinic & triclinic & triclinic & monoclinic \\
\hline Space group & $P-1$ & $P-1$ & $P-1$ & $C c$ \\
\hline$a(\AA)$ & $8.5296(14)$ & $8.5511(4)$ & $8.6281(5)$ & $14.2981(7)$ \\
\hline$b(\AA)$ & $8.8986(14)$ & $8.7942(5)$ & $8.9010(5)$ & $17.5489(8)$ \\
\hline$c(\AA)$ & $10.5757(15)$ & $10.4459(5)$ & $10.6287(7)$ & $13.4398(7)$ \\
\hline$\alpha\left(^{\circ}\right)$ & $71.300(4)$ & $70.748(2)$ & $72.133(2)$ & 90.00 \\
\hline$\beta\left(^{\circ}\right)$ & $78.698(4)$ & $78.9820(10)$ & $78.500(2)$ & $114.6570(10)$ \\
\hline$\left.x^{\circ}\right)$ & $74.264(5)$ & $74.252(2)$ & $74.6320(10)$ & 90.00 \\
\hline$V\left(\AA^{3}\right)$ & $726.59(19)$ & $709.29(6)$ & $742.90(8)$ & $3064.8(3)$ \\
\hline$Z$ & 1 & 1 & 1 & 4 \\
\hline$\rho_{\mathrm{c}}\left(\mathrm{g} \mathrm{cm}^{-3}\right)$ & 1.429 & 1.474 & 1.527 & 1.743 \\
\hline$F(000)$ & 323 & 325 & 346 & 1608 \\
\hline$T / \mathrm{K}$ & $298(2)$ & $298(2)$ & $298(2)$ & $298(2)$ \\
\hline$\mu(\mathrm{Mo}-\mathrm{K} \alpha) / \mathrm{mm} 1$ & 0.512 & 0.664 & 0.791 & 1.338 \\
\hline Data/param./restr. & $2748 / 196 / 0$ & $2607 / 196 / 0$ & 2877 / $196 / 0$ & $6509 / 410 / 2$ \\
\hline GOF & 1.023 & 1.108 & 1.131 & 1.065 \\
\hline$R 1, w R 2(I>2 \sigma(I))$ & $0.0592 / 0.1414$ & $0.0279 / 0.0720$ & $0.0218 / 0.0561$ & $0.0361 / 0.0913$ \\
\hline$R 1, w R 2$ (all data) & $0.0792 / 0.1543$ & $0.0300 / 0.0733$ & $0.0223 / 0.0569$ & 0.0399 / 0.0939 \\
\hline Large diff. peak / hole $\left(\mathrm{e} \AA^{-} 3\right)$ & $0.974 /-0.689$ & $0.282 /-0.256$ & $0.506 /-0.401$ & $1.593 /-0.964$ \\
\hline
\end{tabular}

ligand $\mathrm{HL}$ shows characteristic $\mathrm{C}=\mathrm{O}$ stretching vibration at $1720 \mathrm{~cm}^{-1}$. The absorption bonds around $3400 \mathrm{~cm}^{-1}$ corresponds to the presence of hydroxyl group. The infrared spectral peaks around $3064 \mathrm{~cm}^{-1}$ are due to the aromatic $\mathrm{C}-\mathrm{H}$ vibrations. The compounds 1-4 show similar types of vibration frequencies. An intense and broad band at about $3200 \mathrm{~cm}^{-1}$ suggests the presence of water molecule. The $v_{a \mathrm{~s}}\left(\mathrm{COO}^{-}\right)$band is observed at around 1607 $\mathrm{cm}^{-1}$, while the $v_{\mathrm{s}}\left(\mathrm{COO}^{-}\right)$vibration is observed at about $1396 \mathrm{~cm}^{-1}$. The separation value $\mathrm{d} v\left(v_{a s}\left(\mathrm{COO}^{-}\right)-\right.$ $v_{\mathrm{s}}\left(\mathrm{COO}^{-}\right)$is about $211 \mathrm{~cm}^{-1}$ which is in good agreement with the monodentate coordination mode features shown by the results of crystal structures. ${ }^{20}$

\section{2. Crystal Structures of Complexes 1-4}

The solid structures of complexes 1-4 were determined by single-crystal X-ray diffraction. The crystallograp-

Table 2. Selected Bond Distance (Å) and Angles (deg) for $\mathbf{1}$.

\begin{tabular}{cccc}
\hline Mn1-O1 & $2.146(2)$ & Mn1-O3 & $2.173(2)$ \\
Mn1-N2 & $2.292(2)$ & O1-C10 & $1.240(3)$ \\
O2-C10 & $1.239(4)$ & & \\
O1-Mn1-O1 $^{\text {iii }}$ & 180.0 & O1-Mn1-O3 & $89.95(8)$ \\
O1-Mn1-O3 $^{\text {iii }}$ & $90.05(8)$ & O1-Mn1-N2 & $88.40(8)$ \\
O1-Mn1-N2 $^{\text {ii }}$ & $91.60(9)$ & O3 $^{\text {iii }}-\mathrm{Mn} 1-\mathrm{N} 2^{\mathrm{i}}$ & $89.79(8)$ \\
O3-Mn1-N2 $^{\mathrm{i}}$ & $90.21(8)$ & & \\
\hline
\end{tabular}

Symmetry codes: (i) $-x+1,-y+1,-z+1$; (ii) $x, y+1, z-1$; (iii) $-x+1,-y+2,-z$.

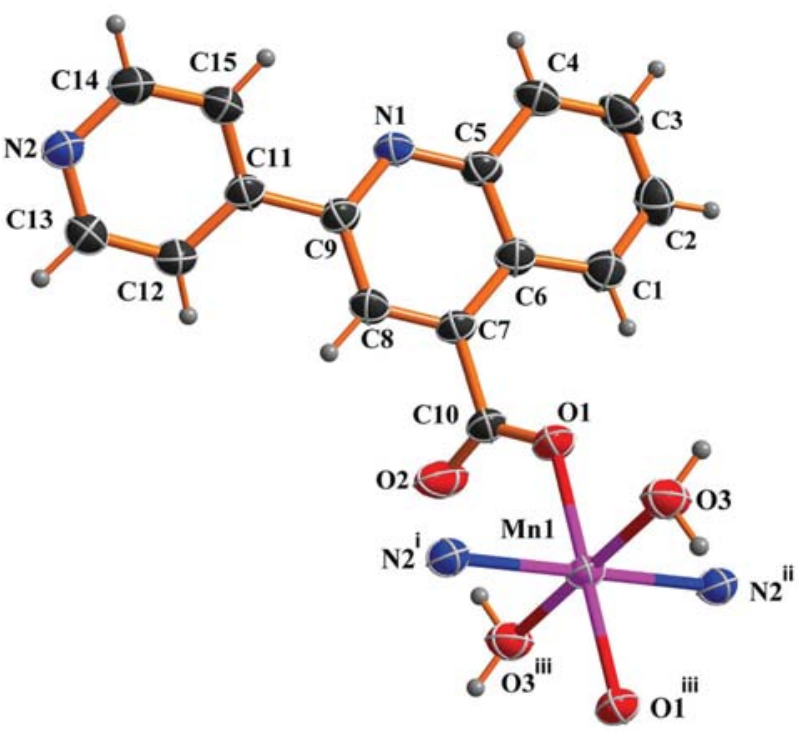

Figure 1. The coordination environment of $\mathrm{Mn}(\mathrm{II})$ in $\mathbf{1}$ at $50 \%$ probability displacement. Symmetry codes: (i) $-x+1,-y+1,-z+1$; (ii) $x, y+1, z-1$; (iii) $-x+1,-y+2,-z$.

hic and data collection parameters for complexes 1-4 are given in Table 1; selected bond lengths and angles are listed in Tables 2, 3 and S1, S2.

The result of single crystal analysis indicates that complexes 1-3 are isomorphous. They all crystallize in triclinic system, space group $P \overline{\mathrm{l}}$, therefore, the crystal structure of $\mathbf{1}$ is described in detail herein as the example. The ORTEP plots of 1-3 are shown in Figures 1, S1 and S2. 
There are half of the Mn(II) center, one deprotonated ligand $\mathrm{L}^{1-}$, one coordinated water molecule, and one solvent water molecule in the asymmetric unit of $\mathbf{1}$. As depicted in Fig. 1, the Mn(II) center is six-coordinated in pseudo-octahedral coordination geometry. The equatorial plane was defined by two coordination water molecules $\left(\mathrm{O} 3\right.$ and $\left.\mathrm{O} 3^{\mathrm{iii}}\right)$, and two $\mathrm{N}$ atoms $\left(\mathrm{N} 2^{\mathrm{i}}\right.$ and $\left.\mathrm{N} 2^{\mathrm{ii}}\right)$ from two different pyridine rings. The axial positions are occupied by the monodentate carboxylic $\mathrm{O}$ atoms $\left(\mathrm{O} 1\right.$ and $\mathrm{O} 1^{\mathrm{iii}}$ ). The sum of the equatorial bond angles are $360.0(8)^{\circ}$, which ensures the planarity of the equatorial plane. The axial O1-Mn1-O $1^{\text {iii }}$ bond angle of $180.0^{\circ}$ clearly indicates the linear configuration. As shown in Table 2, the equatorial bond length distances between the $\mathrm{Mn}$ atom and the N, O atoms, 2.293(2) and 2.173(2) $\AA$, are longer than the axial Mn1-O1 distance, 2.146(2) $\AA$, showing the squashed octahedron configuration.
Compared with the metal complexes based on $\mathbf{H L}_{\mathbf{1}}$ and $\mathbf{H} \mathbf{L}_{2},{ }^{14,15} \mathbf{H L}$ in $\mathbf{1}$ is more planer, as evidenced by the dihedral angle between the pyridine ring and the quinoline heterocycle being $21.01(1)^{\circ}$. The carboxylate group of $\mathbf{H L}$ in complex 1 adopts a monodentate coordination mode, while in previous reported dinuclear complex $\left[\mathrm{Mn}_{2}\left(\mathrm{~L}_{1}\right)_{4}(\mathrm{MeOH})_{4}\right]$, the carboxylate group adopts a synsyn bidentate coordination mode. ${ }^{14}$

As can be seen from Figure 2, the Mn(II) cations are bridged by the carboxylate and pyridine group to form a double chain structure extending along the crystallographic $[0-11]$ direction with the nearest intrachain $\mathrm{Mn} \cdots \mathrm{Mn}$ distance of 11.431(2) $\AA$. In complex 1, the water molecules, acting as both hydrogen-donors and hydrogen-acceptor, play a crucial role in determining the supramolecular structure. First of all, the lattice water molecules are bond to the chain via $\mathrm{O} 4-\mathrm{H} 4 \mathrm{~A} \cdots \mathrm{O} 2$, meanwhile the intrachain

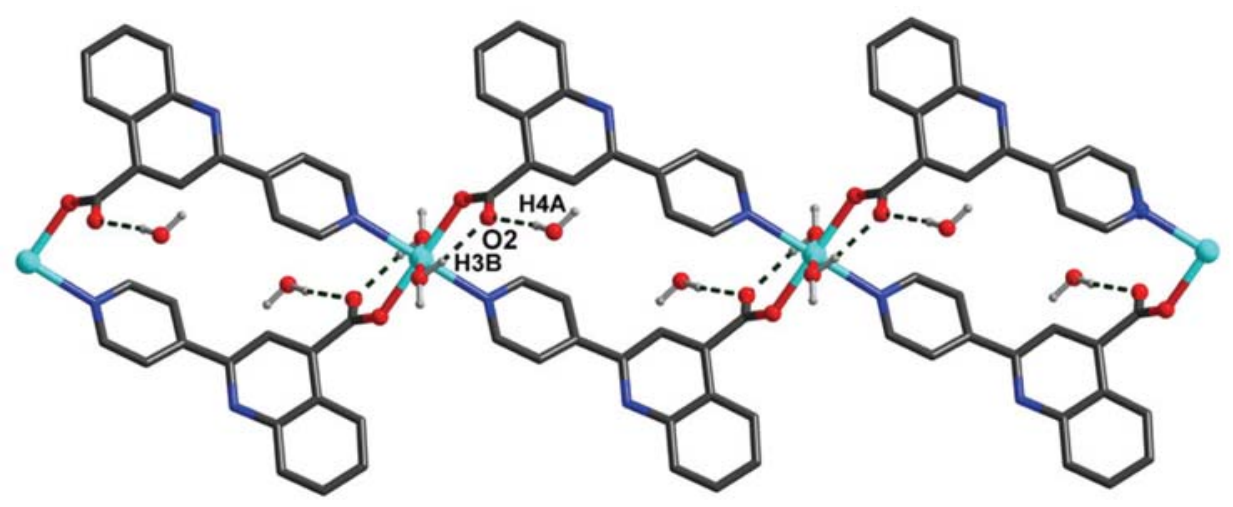

Figure 2. The one-dimensional double chain structure of $\mathbf{1}$.

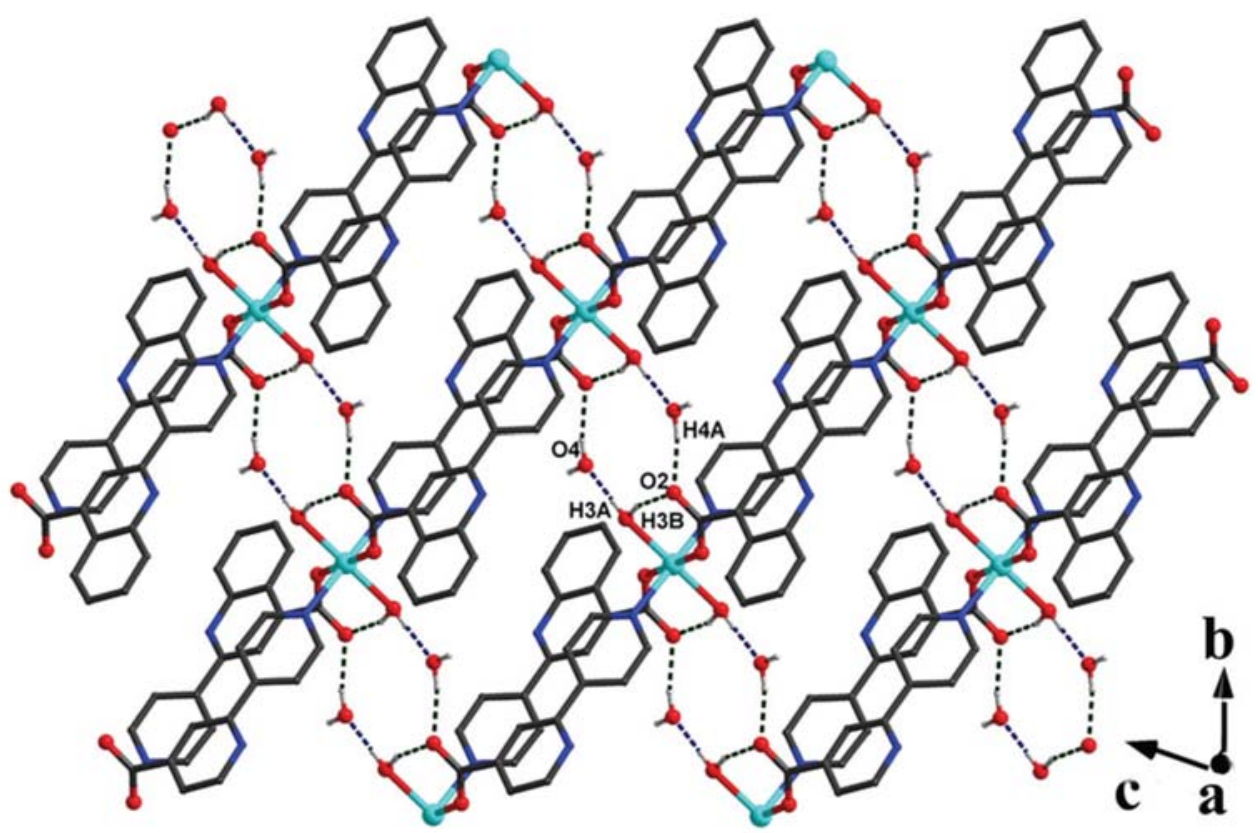

Figure 3. The H-bond-driven 2-D sheet extended in the crystallographic $b c$ plane in $\mathbf{1}$. 


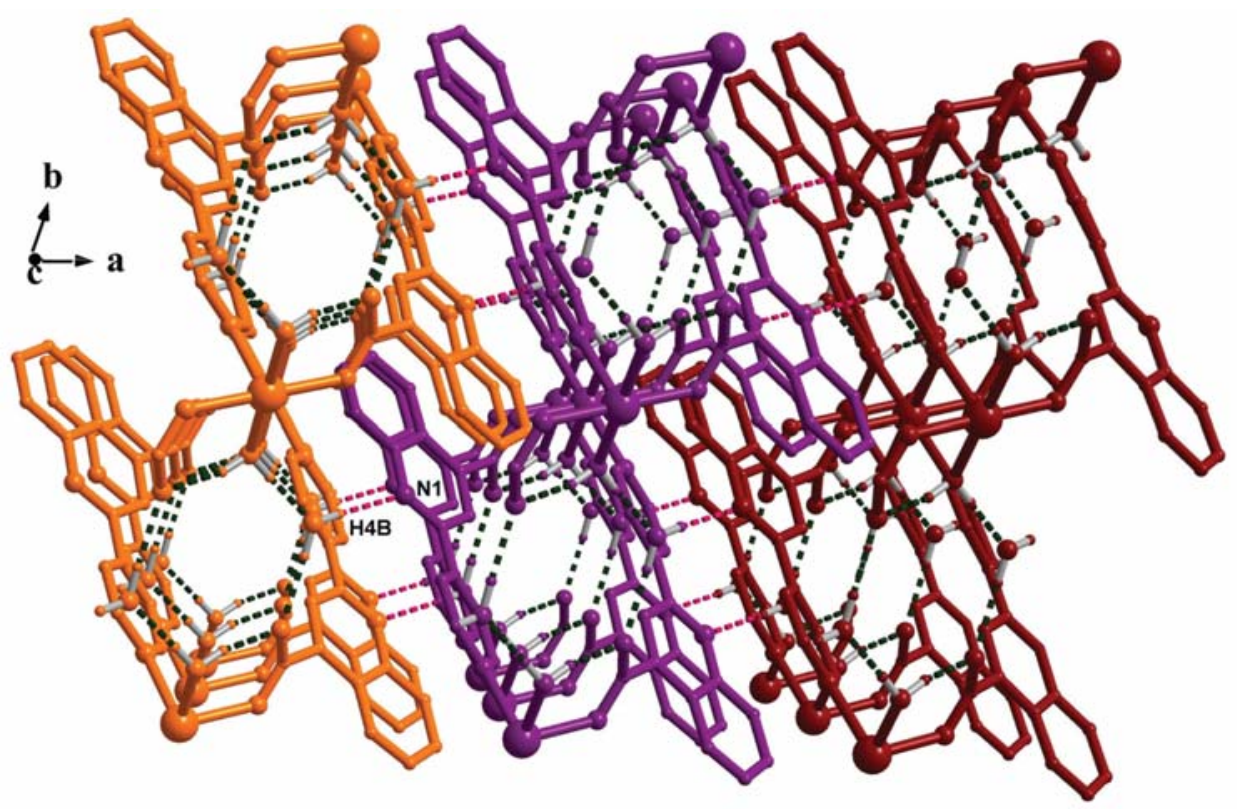

Figure 4. The 3D hydrogen-bonded network of 1.

hydrogen bonding interactions between the coordinated water molecules and the uncoordinated carboxylic $\mathrm{O}$ atoms are also observed (O3-H3B ‥O2). Such 1D chains are aligned side by side in the $b c$ plane, and the adjacent chains are held together through interchain hydrogen bonds between the coordinated water molecules and the latticed water molecules $(\mathrm{O} 3-\mathrm{H} 3 \mathrm{~A} \cdots \mathrm{O} 4)$ into a supramolecular layer (Figure 3).

These supramolecular layers are stacked along the crystallography $a$ axis as a -AA-fashion. The further $\mathrm{O} 4-\mathrm{H} 4 \mathrm{~A} \cdots \mathrm{N} 2$ interactions involving the latticed water molecules and the uncoordinated quinoline $\mathrm{N}$ atoms link these sheets into a three dimensional network (Figure 4).

Contrary to the formation of 1D infinite singlechains in complexes 1-3, a 3D polymeric architecture of complex 4 was built when $\mathrm{AgNO}_{3}$ is used for the self-as-

Table 3 Selected Bond Distance ( $\AA$ ) and Angles (deg) for 4.

\begin{tabular}{crcr}
\hline Ag1-N3 & $2.357(3)$ & Ag1-O6 & $2.437(5)$ \\
Ag1-O5 & $2.440(4)$ & Ag1-N1 & $2.494(3)$ \\
Ag2-N4 & $2.177(3)$ & Ag2-N2 & $2.215(4)$ \\
Ag2-O4 & $2.354(3)$ & O1-C10 & $1.221(6)$ \\
O2-C10 & $1.236(6)$ & O3-C25 & $1.250(5)$ \\
O4-C25 & $1.246(6)$ & & \\
N3-Ag1-O6 & $136.74(17)$ & N4-Ag2-N2 & $148.03(15)$ \\
N3-Ag1-O5 & $119.33(13)$ & O6-Ag1-O5 & $77.77(16)$ \\
N3-Ag1-N1 & $98.09(11)$ & O6-Ag1-N1 & $109.50(15)$ \\
O5-Ag1-N1 & $115.95(12)$ & N2-Ag2-O4 & $88.81(13)$ \\
N4 - Ag2-O4 & & & \\
\hline
\end{tabular}

Symmetry codes: (i) $x+1 / 2,-y+3 / 2, z-1 / 2$; (ii) $x,-y+1, z-1 / 2$.

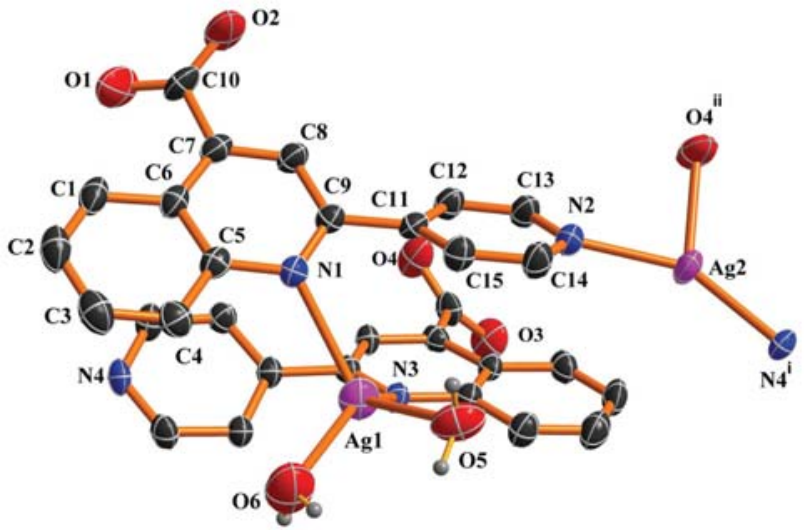

Figure 5. The coordination environment of $\operatorname{Ag}(\mathrm{I})$ in 4 at $50 \%$ probability displacement. Symmetry codes: (i) $x+1 / 2,-y+3 / 2, z-1 / 2$; (ii) $x,-y+1, z-1 / 2$.

semble reaction. Crystal structure analysis data reveal that 4 crystallizes in monoclinic system, space group $C c$.

Two crystallographically independent $\mathrm{Ag}^{+}$ions, two deprotonated ligands $\mathbf{L}^{1-}$, two coordinated water molecules and three solvent water molecules compose the asymmetric unit of 4. As illustrated in Figure 5, the Ag1 and $\mathrm{Ag} 2$ coordination environments are distinct from each other. $\mathrm{Ag} 1$ is four-coordinated by two water molecules (O5 and $\mathrm{O6}$ ), and two $\mathrm{N}$ atoms (N3 and N1) from two quinoline rings, forming a distorted tetrahedral geometry. However, $\mathrm{Ag} 2$ is three-coordinated with triangle coordination geometry surrounded by two pyridine $\mathrm{N}$ atoms ( $\mathrm{N} 2$ and $\left.\mathrm{N} 4^{\mathrm{i}}\right)$, and one monodentate carboxyl oxygen atom $\left(\mathrm{O} 4^{\mathrm{ii}}\right)$. The Ag-O bond lengths are in the range of 2.354(3)-2.441(4) $\AA$, which all fall in the normal range 


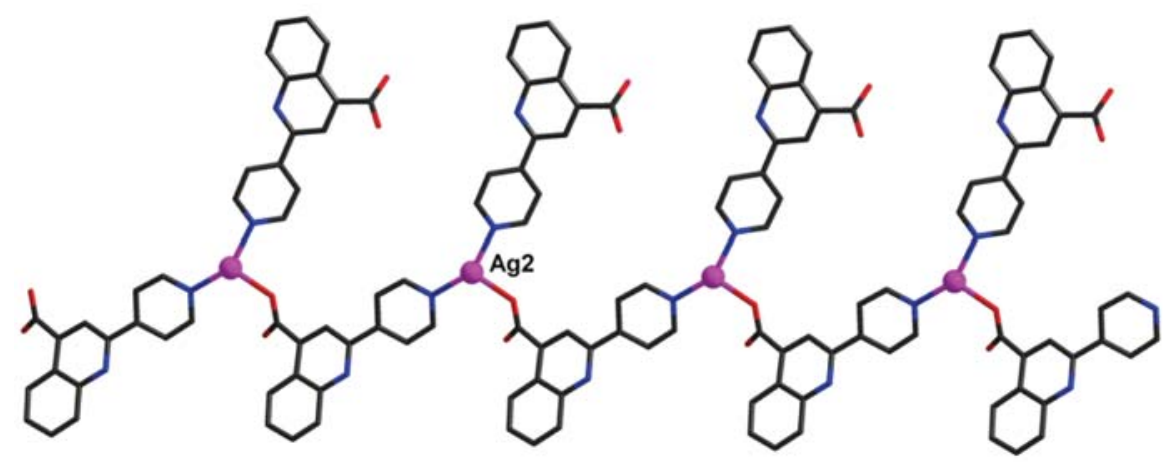

Figure 6. The one-dimensional chain structure in complex 4.

and are in agreement with those values in the previous report. $^{21}$

The deprotonated ligand $\mathbf{L}^{1-}$ acts as bridging bidentate ligand in complexes 1-3 using the pyridine $\mathrm{N}$ and carboxylate $\mathrm{O}$ atoms. While $\mathbf{L}^{1-}$ displays two different coordination modes in complex 4 . One kind of $\mathrm{L}^{1-}$ anion presents terminal bidentate coordination mode using the pyridine N2 and quinoline N1 atoms, keeping the carboxyl group uncoordinated. The coordination mode of the other kind of $\mathbf{L}^{1-}$ can be described as tridentate bridge, the pyridine $\mathrm{N} 4$, quinoline $\mathrm{N} 3$ and carboxyl $\mathrm{O} 4$ atoms are all involved in coordination.

In the structure of $\mathbf{4}$, the $\mathrm{Ag} 2$ cations are connected with three $\mathrm{L}^{1-}$ ligands to form $1 \mathrm{D}$ chain architecture, and the shortest $\mathrm{Ag} \cdots \mathrm{Ag}$ distance is 11.318(2) $\AA$ (Figure 6). These one-dimensional chains are aligned in an -AB- fas- hion in the crystallographic $a c$ plane, and are further connected together via Ag1-N1 and Ag1-N3 linkages to form the 3D microporous network with circular channels along $c$ axis, in which the lattice $\mathrm{H}_{2} \mathrm{O}$ molecules are present (Figure 7).

\section{3. Photoluminescence Properties of HL, 3 and 4}

Photoluminiscence properties of the $\mathrm{d}^{10}$ metal complexes $\mathbf{3}$ and $\mathbf{4}$ as well as the ligand HL in dimethylsulfoxide solution were measured. Their emission spectrum is shown in Figure 8.

Upon excitation at $345 \mathrm{~nm}$ at room temperature, the ligand emits strong fluorescence centered at $402 \mathrm{~nm}$, resulting from the ligand-centered (LC) $\pi^{*}-\pi$ and $\pi^{*}-n$

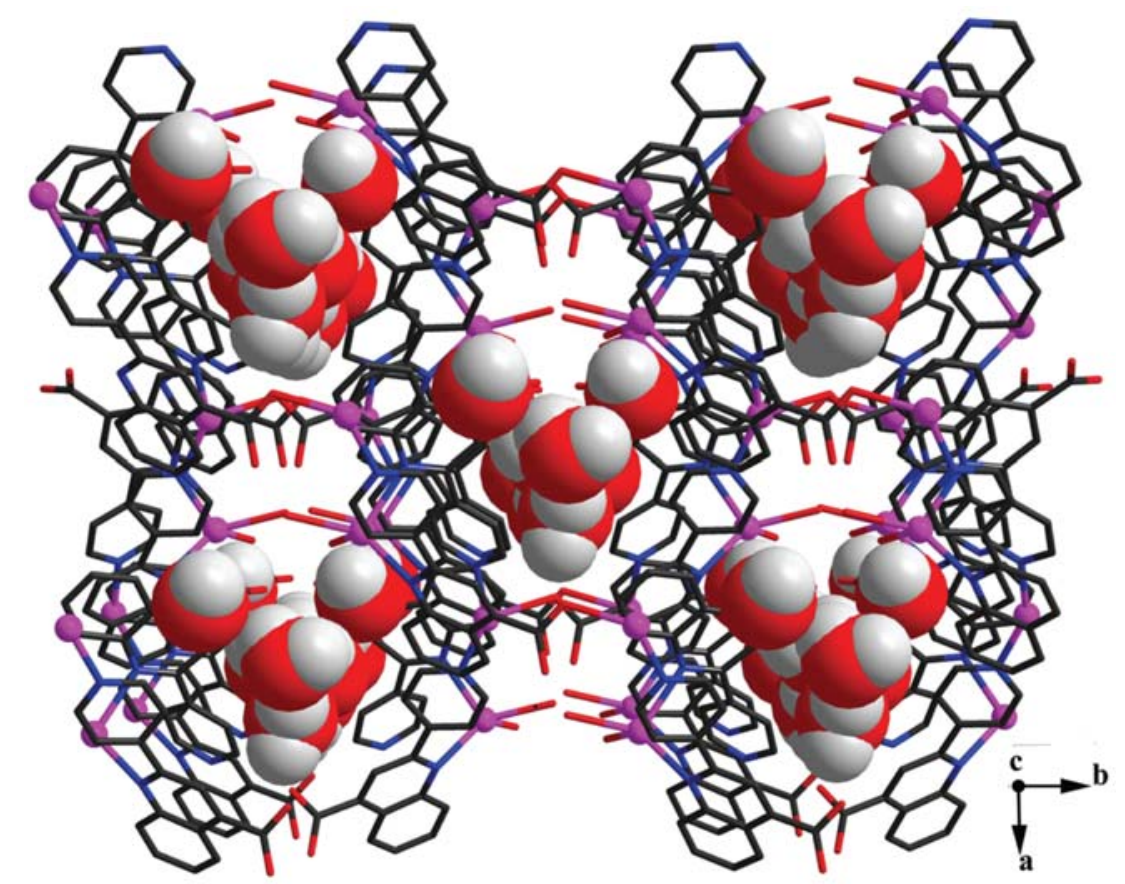

Figure 7. The 3D network of complex 4, with the water solvat molecules shown in space-filling format. 


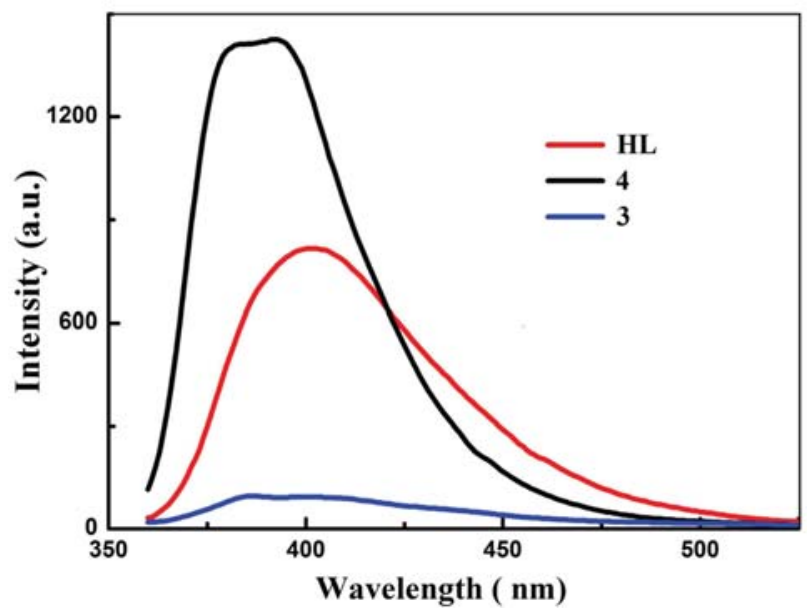

Figure 8. Photoluminescence spectra of HL, 3 and 4 in DMSO solution at room temperature. $\left(\lambda_{\mathrm{ex}}=345 \mathrm{~nm}\right)$

relaxations. ${ }^{15}$ Compared with $\mathbf{H L}$, in complex $\mathbf{3}$, a blue shift of $16 \mathrm{~nm}$ in the emission maxima and much weaker fluorescence intensity is observed. This is probably caused by the reduced $\pi-\pi$ conjugated effect upon coordination to the $\mathrm{Cd}(\mathrm{II})$ and the non-coplanar arrangement in $\mathbf{3}$. The emission of complex 4 is blue shifted to $392 \mathrm{~nm}$ and the emission intensity is stronger than the ligand which may be ascribed to the increased rigidity of the framework. $^{15,22}$

\section{4. Antibacterial Activities}

In the present study, the in vitro antimicrobial properties of $\mathbf{H L}$ and its complexes 1-4 expressed as $\mathrm{IC}_{50}$ are presented in Table 4. Known antibiotic like streptomycin was used as control drug.

As shown in Table 4, against the all tested bacteria, free ligand HL and complex $\mathbf{1}$ were inactive under the tested conditions. For $\mathbf{2} \mathbf{- 4}$, the introduction of metal ions on ligand is endowed with improved inhibition activity. Complex 2 shows its moderate activity towards gram-positive strain. Complex 3 exhibited an enhancement of antibacterial level against gram-positive strains among all the test compounds. The action of the test compounds 2 and $\mathbf{3}$ on gram-positive bacteria is better than that on gram-negative bacteria, which is the same as Co or $\mathrm{Cd}$ complexes based on $\mathbf{H L}_{\mathbf{1}}$ and $\mathbf{H L}_{\mathbf{2}} \cdot{ }^{14,15}$ While the antibacterial activities observed for $\mathbf{1}-\mathbf{3}$ are all poorer than the corresponding previously reported metal complexes derived from $\mathbf{H L}_{\mathbf{1}}$ and $\mathbf{H L}_{\mathbf{2}}$, ${ }^{14,15}$ which can be ascribed to the lack of chelate effect of the carboxylic ligand in 1-3. $\mathrm{Ag}(\mathrm{I})$ involved complex 4 exhibits activity towards gramnegative strain $P$. aeruginosa with $\mathrm{IC}_{50}$ value of 6.74 $\mu \mathrm{g} / \mathrm{mL}$. This selective activity can be attributed to the nature of the Ag ion. ${ }^{21,23}$

\section{Conclusions}

Chain like Mn(II), Co(II) and Cd(II) complexes and $3 \mathrm{D}$ network $\mathrm{Ag}(\mathrm{I})$ complex with the quinoline carboxylic ligand 2-(pyridin-4-yl)quinoline-4-carboxylic acid were synthesized and their crystal structures were determined. The ligand and its $\mathrm{Cd}(\mathrm{II})$ and $\mathrm{Ag}(\mathrm{I})$ complexes are luminescent with maximum emission wavelength at $402 \mathrm{~nm}$, $386 \mathrm{~nm}$ and $382 \mathrm{~nm}$, respectively. The compounds were screened for their antibacterial activity. The bioassay results indicate that $\mathrm{Co}$ (II) and $\mathrm{Cd}$ (II) complexes exhibit antibacterial activity against gram-positive bacteria $B$. subtilis and $S$. aureus, and $\operatorname{Ag}(\mathrm{I})$ complex exhibits antibacterial activity against $P$. aeruginosa. The present observations demonstrate that the modulation of antibacterial activity can be achieved by the coordination geometrical shape and the nature of the central atoms.

\section{Supplementary Material}

Crystallographic data (excluding structure factors) for the structural analysis have been deposited with the Cambridge Crystallographic Data Center as supplementary publication Nos. CCDC 1456423 (1), 1456422 (2), 1456421 (3) and 1496618 (4). Copies of the data can be obtained free of charge via www.ccdc.ac.uk/conts/retrieving.html (or from The Director, CCDC, 12 Union Road, Cambridge CB2 1EZ, UK, Fax: +44-1223-336-033. Email: deposit@ ccdc.cam.ac.uk).

Table 4. Antimicrobial activity of the tested compounds.

\begin{tabular}{ccccc}
\hline \multirow{2}{*}{ Compounds } & \multicolumn{3}{c}{$\begin{array}{c}\text { Half maximal inhibitory concentrations }(\mu g / m L) \\
\text { Gram-negative }\end{array}$} & Gram-positive \\
& E.coli & P.aeruginosa & - & S.aureus \\
\hline HL & - & - & - & - \\
$\mathbf{1}$ & - & - & 18.21 & - \\
$\mathbf{2}$ & - & - & 11.24 & 20.59 \\
$\mathbf{3}$ & - & - & - & 1.87 \\
$\mathbf{4}$ & - & - & 3.74 & - \\
Streptomycin & 3.81 & - & 4.62 \\
\hline
\end{tabular}




\section{References}

1. B. Rosenberg, L. VanCamp, J. E. Trosko, V. H. Mansour, Nature 1969, 222, 385-386. http://dx.doi.org/10.1038/222385a0

2. L. Kelland, Nat. Rev. Cancer 2007, 7, 573-584. http://dx.doi.org/10.1038/nrc2167

3. J. Zhang, F. Zhang, H. Li, C. Liu, J. Xia, L. Ma, W. Chu, Z. Zhang, C. Chen, S. Li, S. Wang, . 2012, 19, 2957-2975. http://dx.doi.org/10.2174/092986712800672067

4. S. H. van Rijt, P. J. Sadler, Drug Discov. Today 2009, 14, 1089-1097. http://dx.doi.org/10.1016/j.drudis.2009.09.003

5. N. T. Huy, D. T. Uyen, A. Maeda, D. T. X. Trang, T. Oida, S. Harada, K. Kamei, Antimicrob. Agents Chemother. 2007, 51 , 350-353. http://dx.doi.org/10.1128/AAC.00985-06

6. K. Kaur, M. Jain, R. P. Reddy, R. Jain, Eur. J. Med. Chem. 2010, 45, 3245--3264. http://dx.doi.org/10.1016/j.ejmech.2010.04.011

7. V. Oliveri, M. L. G iuffrida, G. Vecchio, C. Aiello, M. Viale, Dalton Trans. 2012, 41, 4530-4535. http://dx.doi.org/10.1039/c2dt12371a

8. H. Jiang, J. E. Taggart, X. Zhang, D. M. Benbrook, S. E. Lind, W. Q. Ding, Cancer Lett. 2011, 312, 11-17. http://dx.doi.org/10.1016/j.canlet.2011.06.032

9. C. M. Darby, C. F. Nathan, J. Antimicrob. Chemother. 2010, $65,1424-1427$. http://dx.doi.org/10.1093/jac/dkq145

10. S. F. Vanparia, T. S. Patel, N. A. Sojitra, C. L. Jagani, B. C. Dixit, P. S. Patel, R. B. Dixit, Acta Chim. Slov. 2010, 57, 660-667.

11. R. Mekheimer, E. K. Ahmed, A. F. Khattab, Bull. Chem. Soc. Japan 1998, 66, 2936-2940.

http://dx.doi.org/10.1246/bcsj.66.2936
12. S. Das, H. Kim, K. Kim, J. Am. Chem. Soc. 2009, 131, 3814-3815. http://dx.doi.org/10.1021/ja808995d

13. P. Wang, Y. J. Zhang, J. Qin, Y. Chen, Y. Zhao, J. Mol. Struct. 2015, 1083, 95-100. http://dx.doi.org/10.1016/j.molstruc.2014.11.048

14. J. Qin, F. X. Li, L. Xue, N. Lei, Q. L. Ren, D. Y. Wang, H. L. Zhu, Acta Chim. Slov. 2014, 61, 170-176.

15. N. Lei, Q. L. Ren, Y. P. Liu, J. Li, P. Cong, J. Qin, H. L. Zhu, J. Mol. Struct. 2014, 1067, 220-224. http://dx.doi.org/10.1016/j.molstruc.2014.03.052

16. Bruker, SMART and SAINT. Bruker AXS Inc., Madison, Wisconsin, USA, 2002.

17. G. M. Sheldrick, SADABS. Program for Empirical Absorption Correction of Area Detector, University of Göttingen, Germany, 1996.

18. G. M. Sheldrick, Acta Crystallogr. 2008, A64, 112-122. http://dx.doi.org/10.1107/S0108767307043930

19. Q. L. Ren, S. S. Zhao, L. X. Song, S. S. Qian, J. Qin, J. Coord. Chem. 2016, 69, 227-237. http://dx.doi.org/10.1080/00958972.2015.1110240

20. X. H. Bu, M. L. Tong, Y. B. Xie, J. R. Li, H. C. Chang, S. Kitagawa, J. Ribas, Inorg. Chem. 2005, 44, 9837-9846. http://dx.doi.org/10.1021/ic050886d

21. S. C. Chen, Z. H Zhang, Q. Chen, L. Q. Wang, J. Xu, M. Y. He, M. Du, X. P. Yang, R. A. Jones, Chem. Commum. 2013, 49, 1270-1272. http://dx.doi.org/10.1039/C2CC36538C

22. D. G. Ding, L. X. Xie, Y. T. Fan, H. W. Hou, Y. Xu, J. Solid State Chem. 2009, 182, 1443-1449. http://dx.doi.org/10.1016/j.jssc.2009.02.026

23. P. O. Asekunowo, R. A. Haque, J. Coord. Chem. 2014, 67, 3649-3663.

http://dx.doi.org/10.1080/00958972.2014.971405

\section{Povzetek}

Štiri kovinske komplekse s kinolinkarboksilatnim ligand iz 2-(piridin-4-il)kinolin-4-karboksilne kisline (HL), $\left\{\left[\mathrm{ML}_{2}\left(\mathrm{H}_{2} \mathrm{O}\right)_{2}\right] \cdot 2 \mathrm{H}_{2} \mathrm{O}\right\}_{n}\left(\mathrm{M}=\mathrm{Mn}^{\mathrm{II}}, \mathbf{1} ; \mathrm{M}=\mathrm{Co}^{\mathrm{II}}, \mathbf{2} ; \mathrm{M}=\mathrm{Cd}^{\mathrm{II}}, \mathbf{3}\right)$ in $\left\{\left[\mathrm{Ag}_{2} \mathrm{~L}_{2}\left(\mathrm{H}_{2} \mathrm{O}\right)_{2}\right] \text { v } 3 \mathrm{H}_{2} \mathrm{O}\right\}_{\mathrm{n}}(\mathbf{4})$ smo sintetizirali z uporabo hidrotermalnih pogojev. Spojine smo okarakterizirali s pomočjo elementne analize, IR spektroskopije ter določili strukture z monokristalno rentgensko difrakcijo. Kompleksi 1-3 imajo 1D verižno strukturo, ki je nadalje preko vodikovih vezi medsebojno povezana, da tvori 3D supramolekularno mrežo. Kompleks 4 ima 3D strukturo. Raziskali smo tudi fluorescenčne lastnosti in antibakterijsko aktivnost teh spojin. 